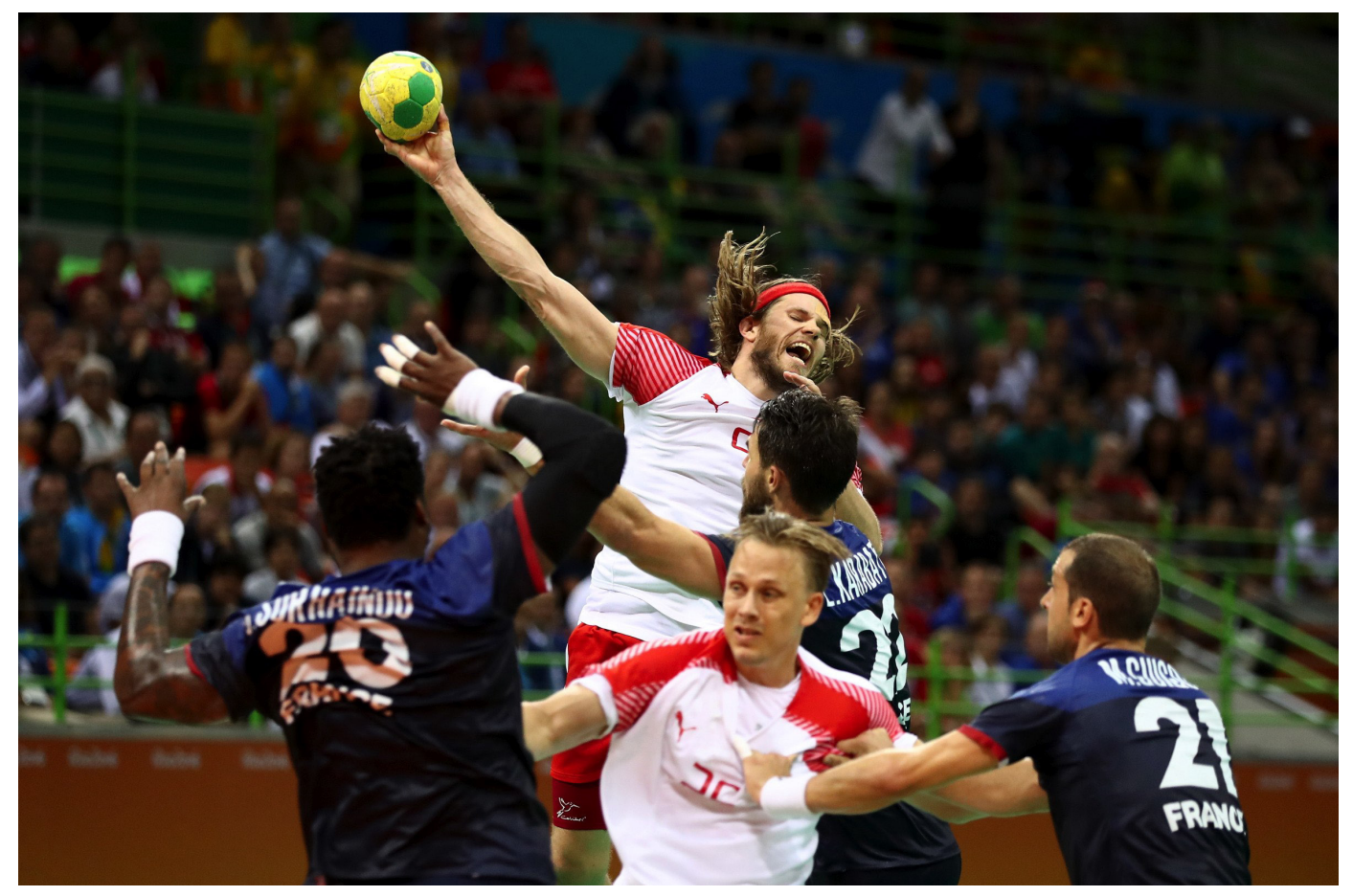

\title{
Hvilken sportsnation er bedst i Norden?
}

\section{En analyse af Danmark, Finland, Norge og Sveriges internationale sportsresultater - historisk og aktuelt}

\section{MICHAEL ANDERSEN, Skandinavisk Netværk for Eliteidræt ${ }^{1}$}

Denne artikel sætter fokus på eliteidræt i Danmark, Finland, Norge og Sverige ud fra historiske og aktuelle perspektiver. Hvorfor har nationerne valgt fire forskellige eliteidrætsmodeller? Hvilke nationer prioriterer vinter- eller sommersportsgrene og hvilke sportsgrene - olympiske og ikke-olympiske står stærkest i de enkelte nationer? Disse spørgsmål besvares på de følgende sider.

1 Skandinavisk Netværk for Eliteidræt (SNE) er et tværinstitutionelt samarbejde mellem Sektion for Idræt, Aarhus Universitet (Danmark), Institutionen för kost- og idrottsvetenskap, Göteborgs Universitet (Sverige), Norges Idrettshøgskole (Norge) og Department of Health and Sport Sciences, University of Jyväskylä (Finland). Netværket blev etableret pr. 1.1.2016 med formålet at opnå større værdi og mere kvalitet inden for uddannelse, forskning og formidling i eliteidræt i Norden. Yderligere oplysninger om SNE på websitet: www.sne.au.dk 


\author{
MICHAEL ANDERSEN \\ Selvstændig konsulent \\ MA57 Consulting, www.ma57.dk \\ micand57@gmail.com
}

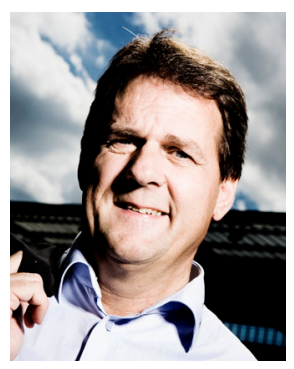

Denne artikel sætter fokus på eliteidræt i Danmark, Finland, Norge og Sverige ud fra historiske og aktuelle perspektiver. De fire nordiske nationer har langt flere ligheder end forskelle, idet alle fire nationer har skabt stærke velfærdsmodeller, som ofte beundres af mennesker både i og uden for Norden. Denne model er udgangspunktet for værdier, normer, strukturer og organisering af en række samfundsområder, herunder idræt. Alle fire nationer rangerer højt på internationale ranglister over f.eks. økonomi, uddannelse, sundhed eller tillid til offentlige myndigheder. Men hvordan klarer de fire nationer sig, både globalt og indbyrdes i Norden, når det handler om eliteidræt? Hvorfor har nationerne valgt fire forskellige eliteidrætsmodeller? Hvilke nationer prioriterer vinter- eller sommersportsgrene og hvilke sportsgrene - olympiske og ikke-olympiske - står stærkest i de enkelte nationer? Disse spørgsmål besvares på de følgende sider.

\title{
INTRODUKTION: KOMPARATIVE UNDERSØGELSER INDEHOLDER (ALTID) METODISKE UDFORDRINGER
}

Det er vanskeligt at udarbejde valide komparative analyser af de enkelte nationers resultater i international eliteidræt. Det skyldes primært en række metodiske udfordringer: Hvilke olympiske og ikke-olympiske sportsgrene skal indgå i analysen? Hvilke internationale konkurrencer - Olympiske Lege, Verdens- og Europamesterskaber, World Cups og særlige events som f.eks. Grand Slam-turneringer i tennis, Giro d'Italia, Tour de France og Vuelta e Espana i cykling, Formel 1 i motorsport eller PGA Tour i golf - skal analysen omfatte? Hvordan skal vægtningen af medaljer (guld, sølv og bronze) være i forhold til f.eks. top 6, top 8 eller top 10-placeringer i de enkelte konkurrencer? Hvordan skal analysen sammenligne sportsgrene med mange discipliner som f.eks. roning, cykling og svømning med sportsgrene med kun én disciplin som f.eks. håndbold og ishockey, der har samme regelsæt for kvinder og mænd? Og skal de forskellige sportsgrene som f.eks. atletik, fodbold, skateboard og klatring vægtes forskelligt eller ligeværdigt i forhold til de enkelte sportsgrenes internationale status? 
Disse metodiske udfordringer afholder imidlertid ikke forsknings- og analyseinstitutioner, medier og andre fra at stille spørgsmålet: Hvilke nationer klarer sig bedst i internationale sportskonkurrencer, både historisk og aktuelt?

Der er konsensus om at mange forskellige faktorer har indflydelse på en nations sportslige resultater ${ }^{2}$. En af de mest anerkendte internationale analyser er "SPLISS-undersøgelsen", som fremhæver, at en nations befolkningsstørrelse (antal indbyggere), økonomisk velstand (BNP), politisk system og religiøse forhold har afgørende indflydelse på nationens sportsresultater ${ }^{3}$. En af analysens væsentligste konklusioner er, at disse fire forhold kan forklare mere end halvdelen af en nations succes eller fiasko i internationale sportskonkurrencer. Den anden halvdel kan forklares ud fra ni faktorer, som er mere eller mindre udviklet i den enkelte nations eliteidrætssystem: Økonomiske ressourcer til eliteidræt, ledelse og organisation af idrætspolitik, idrætsdeltagelse, talentidentifikation og -udvikling, support under og efter atleternes karriere, træningsfaciliteter, coaching og træneruddannelse, deltagelse i nationale og internationale konkurrencer samt forskning og innovation i eliteidræt. "SPLISS-undersøgelsen” sammenligner ovenstående faktorer i 15 nationer over en periode på 4 år i forhold til de sportslige resultater, som nationerne har opnået ved internationale mesterskaber ${ }^{4}$.

2 Green, M. \& Houlihan, B. (2005): Elite sport development. Policy learning and political priorities. (London \& New York: Routledge); Digel, H., Burk, V. \& Fahrner, M. (2006): High-performance sport - An international comparison (Weilheim/Teck: Bräuer), Bergsgard, N.A., Houlihan, B. Mangset, P. Nødland, S.I. \& Rommetveldt, H. (2007): Sport Policy: A comparative analysis of stability and change (Elsevier, UK); Shibili, S., Bingham, J. \& Henry, I. (2007): Measuring the Sporting Success of Nations I: Henry, I: Transnational and Comparative Research in Sport: Globalization, Governance and Sport Policy, pp. 61-81 (London: Routledge), Houlihan, B. \& Green, M. (2008): Comparative Elite Sport Development. Systems, structures and public policy (London, UK: Elsevier), Böhlke, N. \& Robinson, L (2009): Benchmarking of elite sport systems, pp. 67-84 I: Management Decision, 47 (1) https://doi.org/10.1108/o0251 og De Bosscher, V., Shibli, S., von Bottenburg, M, De Knop, P. \& Truyens, J. (2010): Developing a method for comparing the elite sport systems and policies of nations: a mixed research methods approach. Journal of Sport Management, 24(5), pp. 567-6oo https://doi.org/10.1123/jsm.24.5.567

3 De Bosscher, V., Shibli, S., Westerbeek, H. \& Van Bottenburg, M. (2015): Successful Elite Sport Policies. An international comparison of the Sport Policy factors Leading to International Sporting Success (SPLISS 2.o) in 15 nations. (Maidenhead: Meyer \& Meyer Sport). Danmark og Finland er blandt de 15 nationer, som indgår i den komparative analyse. Den første version af SPLISS er beskrevet i publikationen: De Bosscher, V., Bingham, J., Shibli, S., Van Bottenburg, M. \& De Knop, P. (2008): The global sporting arms race. An international comparative study on sport policy factors leading to international sporting success (Aachen: Meyer \& Meyer). Analysen omfattende 6 nationer, bl.a. Norge. Yderligere oplysninger om SPLISS på websitet: www.spliss.net

4 Resultaterne er opgjort i perioden 2009-2012. Følgende nationer indgår i den komparative analyse: Brasilien, Canada, Japan, Sydkorea, Australien, Belgien (Fladeren og Wallonien), Danmark, Estland, Finland, Frankrig, Holland, Nordirland, Portugal, Spanien og Schwiez. I den første SPLISS-undersøgelse omfattende seks nationer: Belgien, Canada, Italien, Holland, Storbritannien og Norge. Resultaterne i denne undersøgelse er opgjort i perioden 2003-2004. 
Der er imidlertid også andre faktorer end de nævnte i "SPLISS-undersøgelsen", som har indflydelse på en nations sportslige potentialer og resultater, f.eks. klima og geografi. Vejr, temperaturer og geografi kan i vid udstrækning forklare, hvorfor mindre nationer som f.eks. Sverige, Norge, Finland, Østrig og Schweiz er meget stærke vintersportsnationer, mens stærke sportsnationer som f.eks. Jamaica, Australien, Ungarn og Danmark yderst sjældent vinder medaljer eller kvalificerer sig til OL i vintersportsgrene som langrend, skiskydning, skihop eller bobslæde. Derimod kan det være mere vanskeligt at forklare hvorfor sportsgrene som f.eks. badminton i Danmark, golf i Sverige, skiskydning i Norge, hurtigløb på skøjter i Holland eller bordtennis i Kina er meget populære og succesfulde i netop disse nationer. Det skyldes formentlig historiske traditioner og stærke kulturer, som forstærker både atleternes, tilskuernes og mediernes særlige interesse for netop disse sportsgrene i de pågældende nationer ${ }^{5}$.

\section{FALLES KARAKTERISTIKA: DEN NORDISKE VELFARDSMODEL}

Nationerne i Norden deler i stort omfang fælles historie, kultur, sprog, politisk styreform og religion. Nationerne har især efter 2. verdenskrig udviklet en politisk og økonomisk samfundsmodel - den nordiske velfærdsmodel - med en række fælles karakteristika $^{6}$. De grundlæggende principper bag denne model er, at alle borgere i samfundet har lige adgang til sociale ydelser som f.eks. børnefamilieydelse, kontanthjælp og folkepension uden hensyn til deres sociale baggrund, og at ydelserne ikke er koblet til forsikringsbidrag eller andre former for brugerbetaling. Borgerne er hermed økonomisk sikret i forbindelse med sygdom, ledighed og alderdom. Desuden findes en række stærkt udbyggede offentlige tjenesteydelser i form af daginstitutioner, gratis uddannelsesinstitutioner (folkeskoler, gymnasier og universiteter), gratis sundhedsydelser (lægehjælp, operationer etc.) samt en række sociale ydelser (kontanthjælp, dagpenge og pension).

5 Yderligere information om badminton i Danmark: www.badminton.dk, golf i Sverige: www. spelagolf.se/historia, skiskydning i Norge: www.snl.no/skiskyting, hurtigløb på skøjter i Holland: www.mentalfloss.com/article/55182/why-are-dutch-so-good-speed-skating. Det anslås at der er mere end 300 mio. registrerede bordtennisspillere i Kina - mere end USA's befolkning. Derudover anbefales artiklen: Wijk, J. (2012): The Swedish golf and tennis miracle - two parallel stories, pp. 109-130 I: Andersen, S.S. \& Ronglan, L.T. (eds.): Nordic Elite Sport. Same ambitions - different tracks (Oslo: Universitetsforlaget).

6 Allardt, E. (1975): Att ha, att älska, att vara: om väldfärd i Norden (Lund: Argos) og Christensen, N.F., Petersen, K., Edling, N. \& Haave, P. (red.) (2006): The Nordic Model of Welfare: An Historical Reappracusial (Copenhagen: Museum Tuscalamum Press). 
Den nordiske velfærdsmodel er også karakteriseret ved at høj økonomisk velstand og vækst er forenet med en relativt lige fordeling af indkomsterne ${ }^{7}$. Et vigtigt instrument i den forbindelse er skatter og afgifter, fordi modellen primært finansieres ved skatteudskrivning. Omfordelingen af økonomiske ressourcer er særdeles markant, hvilket bl.a. sker igennem et progressivt skattesystem. Modellens bæredygtighed afhænger derfor i høj grad af, om den er i stand til at opretholde en høj beskæftigelse for begge køn. I praksis har de nordiske nationer gennem politiske kompromiser udviklet forskellige variationer af modellen. Forskellene mellem varianterne af den nordiske velfærdsmodel er især betinget af, hvilke politiske alliancer, som de forskellige politiske partier har indgået i. Udviklingen af den nordiske velfærdsmodel forbindes ofte med stærke socialdemokratiske arbejderbevægelser som drivkraft, men det er samtidig karakteristisk, at der har været en høj grad af konsensus om centrale reformer blandt hovedparten af de politiske partier ${ }^{8}$.

De bærende værdier i den skandinaviske velfærdsmodel er fællesskab, solidaritet og lighed, hvilket betyder at det offentlige (stat, regioner og kommuner) bruger relativt mange økonomiske ressourcer på at skabe gode rammer og vilkår for borgernes kultur- og fritidsliv 9 . I den forbindelse har alle fire nationer udviklet et mangfoldigt og velfungerende foreningsliv inden for bl.a. idræt, hvor et stort antal trænere og ledere - frivilligt eller betalt - påtager sig en række opgaver til glæde og gavn for lokalsamfundets børn og unge. Foreningslivet udgør fundamentet for talent- og elitearbejdet i de enkelte sportsgrene ${ }^{10}$. Derudover er det karakteristisk for de nordiske nationer, at de enkelte sportsgrene er organiseret i specialforbund,

7 Bruttonationalproduktet (BNP) pr. indbygger udtrykker værdien af alle varer og tjenesteydelser, som produceres i et land i løbet af et år, minus de varer som bliver brugt til i denne produktion. BNP. pr. indbygger viser ikke uligheder blandt borgerne, f.eks. i forhold til indkomst eller formue. De fire nordiske nationer har igennem en lang årrække været placeret meget højt på listen over lande med højst BNP. pr. indbyggere. I 2016 var Norge (70.900 \$) placeret som nr. 3 efter Luxemburg (100.800 \$) og Schweiz (80.00o \$). Danmark (53.60o \$) var placeret som nr. 8, Sverige (51.80o \$) som nr. 10 og Finland (43.400 \$) som nr. 15.

8 Dybdal, A. (red.) (2014): Socialdemokratiske tænkere (København: Informations Forlag). Bogen omhandler 17 af de tænkere og politiske praktikere, der har haft størst indflydelse på socialdemokratier i Norden. Blandt disse kan nævnes Alva og Gunnar Myrdal (Sverige), Gro Harlem Brundtland (Norge) og Mogens Lykketoft (Danmark).

9 Den nordiske velfærdsmodel er også kendt som den universielle velfærdsmodel. De to øvrige idealtyper er den liberale velfærdsmodel (bl.a. USA og UK) og den centraleuropæiske velfærdsmodel (bl.a. Tyskland og Holland) - jf. Esping-Andersen, G. (1990): The Three Worlds of Welfare Capitalism (Oxford: Polity Press). For yderligere information om den universielle velfærdsmodel, se f.eks. Larsen, C.A. \& Andersen, J.G (red.) (2015): Den universielle velfærdsstat - funktionsmåde, folkelig opbakning og forandring (Frydenlund Academic).

10 Bergsgard, N.A. \& Norberg, J.R. (2010): Sport and Politics - the Scandinavian way, pp. 567-582. https://doi.org/10.1080/17430431003616191, Støckel. J.T., Strandbu, Å., Solenes, O. Jørgensen, P. \& Fransson, K. (2010): Sport for children and youth in the Scandinavian countries, pp. 625-643 https://doi.org/10.1080/17430431003616332 og Bairner, A. (2010): What's Scandinavian about Scandinavian Sport, pp. 734-743 https://doi.org/10.1080/17430431003616555 I: Sport in Society, 13/4. 
som alle er medlemmer af det nationale idrætsforbund: Norges idrettsforbund (NIF), Riksidrottsförbundet (RF) og Danmarks Idrætsforbund (DIF) og Suomen Olympiakomitea $^{11}$. Specialforbund kan nemlig kun deltage i internationale turneringer og mesterskaber, såfremt de er medlemmer af det nationale idrætsforbund eller den nationale olympiske komité.

\section{HISTORISKE TRADITIONER OG STAERK ELITESPORTSKULTUR I NORDEN}

Det mangfoldige netværk af klubber med kompetente børne- og ungdomstrænere kombineret med høj materiel velstand og gode idrætsfaciliteter har været de væsentligste årsager til, at alle fire nationer igennem mere end et århundrede har været blandt de bedste sportsnationer i verden, ikke mindst i forhold til nationernes relativt beskedne indbyggertal. Især i vintersportsgrene som langrend, skiskydning, alpint skiløb, hurtigløb på skøjter og skihop har Norge, Sverige og Finland været meget dominerende ved vinter-OL, VM og World Cups. Men også i sommersportsgrene som skydning, sejlsport, atletik, cykling, roning, brydning og håndbold har de nordiske nationer vundet relativt mange OL-, VM- og EM-medaljer ${ }^{12}$.

Både Sverige og Danmark var sammen med 11 andre nationer repræsenteret ved det første sommer-OL i moderne tid, som blev afholdt i Athen 1896. Danmark vandt 6 medaljer ved legene i tre sportsgrene: Skydning, vægtløftning og fægtning, mens Sverige måtte rejse hjem uden medaljer fra det første OL. Norge fik olympisk debut ved OL 1900 i Paris, hvor antallet af sportsgrene var vokset fra 9 til 19 og antallet af nationer fra 13 til $24^{13}$. Finland deltog for første gang ved OL 1908 i London som en del af delegationen fra zarriget Rusland, selv om Finland var optaget som selvstændigt medlem af den internationale olympiske komité i 1907. Finland og Helsinki var også vært for OL i 1952, hvilket er den eneste sommer-OL efter 2. verdenskrig, som er afholdt i Norden.

11 Yderligere information om de nationale idrætsforbund er på følgende websites: Norges Idrettsforbund (NIF - www.idrettsforbundet.no), Riksidrottsförbundet (RF - www.rf.se) og Danmarks Idrætsforbund (DIF - www.dif.dk) og Suomen Olympiakomitea (SO - www.olympiakomitea.fi) NIF, SO og DIF er tillige nationale olympiske komitéer i henh. Norge, Finland og Danmark. I Sverige er der en selvstændig olympiske komité - Sveriges Olympiska Kommitté (SOK - www.sok.se) med autonomi i forhold til RF (jf. note 17).

12 I denne artikel er vintersportsgrene defineret som sportsgrene, som indgår i vinter-OL, mens sommersportsgrene er defineret som sportsgrene, som indgår i sommer-OL. De fleste topatleter opfatter deres sportsgrene som en helårsaktivitet, dvs. med forskellige typer af træning (ind- og udland) på forskellige tidspunkter af året. Sportsgrene som f.eks. håndbold og badminton, der er indgår i programmet ved sommer-OL, blev tidligere defineret som vintersportsgrene, primært fordi de foregik indendørs.

13 Olympiske medaljer gennem tiden - se følgende websites: www.olympic.org/olympic-result og www.olympiandatabase.com 
Sverige med et befolkningstal på 9,6 mio. var i første halvdel af det 20. århundrede én af verdens bedste sportsnationer, idet kun USA og Storbritannien vandt flere medaljer end Sverige ved samtlige sommer-OL før 2. verdenskrig ${ }^{14}$. I begyndelsen af 1960'erne, hvor Sovjetunionen og en række østeuropæiske nationer blev mere og mere dominerede gennem "statsamatørisme" og udbredt brug af doping, faldt antallet af medaljer til Sverige ved sommer-OL markant. Sverige er imidlertid stadig i dag nr. 10 på ranglisten over samtlige sommer-OL og dermed historisk den nation i verden, der har klaret sig bedst ved sommer-OL $i$ forhold til nationens befolkningstal. På tilsvarende vis er Finland stadig nr. 14 på ranglisten af historisk bedste nationer ved samtlige sommer-OL, selv om Finland kun vandt en enkelt bronzemedalje ved det seneste OL i Rio. Sverige har også historisk været en meget stærk nation i sportsgrene som fodbold for kvinder og mænd (VM-sølv i 1958 og VM-bronze i 1994), håndbold for mænd (VM-guld i 1954, 1958, 1990 og 1999 samt OL-sølv i 1992, 1996, 2000 og 2012), tennis og golf - altså sportsgrene, som først i de seneste tiår er kommet på det olympiske program. Sverige har indtil dato vundet i alt 493 medaljer (145 guld-, 170 sølv- og 178 bronzemedaljer) ved sommer-OL i 24 forskellige sportsgrene, flest i brydning, atletik og skydning.

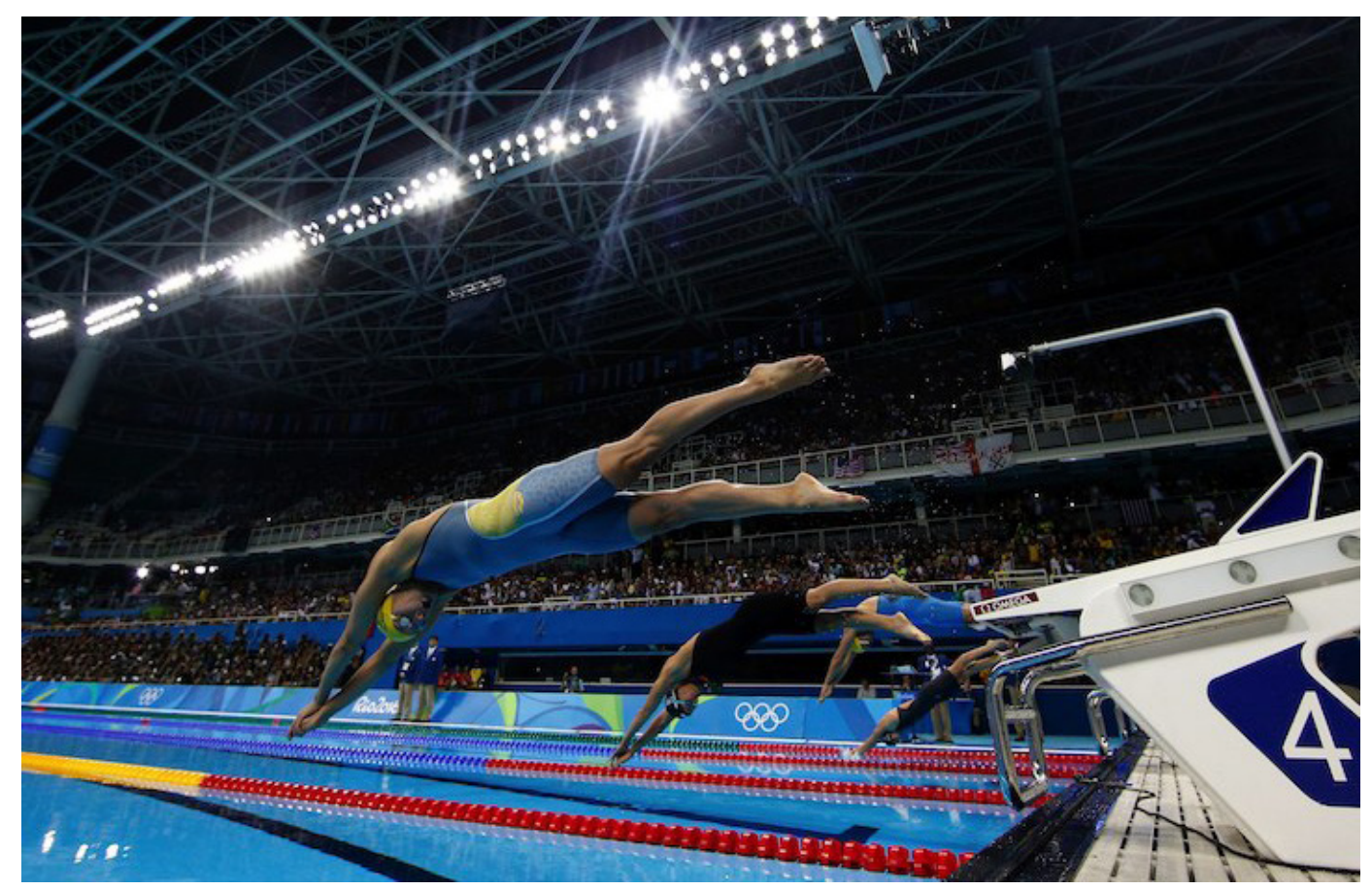

Sara Sjöström var en af Sveriges største atlet-profiler ved OL 2016 med 3 medaljer: OL-guld i 100 meter butterfly efterfulgt af OL-sølv i 200 fri stil og OL-bronze i 100 meter fri stil.

14 Storm, R.K. \& Klaus Nielsen (2017): Er Skandinavien konkurrencedygtig? Danmark, Norge og Sveriges konkurrenceevne i international elitesport, pp. 363-380 I Busch, T., Olaussen, J. O. \& Pettersen, I. J.: Bred og spiss! NTNU Handelshøyskolen 50 år. En Vitenskabelig Jubilæumsantologi (Bergen: Fagbokforlaget). 
Finland, Danmark og Norge har også i forhold til befolkningsstørrelser på henh. 5,5 mio., 5.7 mio. og 5,2 mio. indbyggere klaret sig historisk flot ved sommer-OL. Finland har indtil dato vundet i alt 302 medaljer (101 guld-, 85 sølv- og 117 bronzemedaljer) ved sommer-OL i 12 forskellige sportsgrene, flest i atletik, brydning og gymnastik. Langt de fleste finske OL- medaljer er imidlertid vundet ved sommer-OL før 2. verdenskrig, hvor Finland var én af verdens absolut bedste sportsnationer målt i forhold til indbyggertal. Danmark har indtil dato vundet i alt 194 medaljer (45 guld-, 74 sølv- og 75 bronzemedaljer) ved sommer-OL i 20 forskellige sportsgrene, flest i sejlsport, cykling og roning. Norge har indtil dato vundet i alt 152 medaljer (56 guld-, 49 sølv- og 47 bronzemedaljer) ved sommer-OL i 17 forskellige sportsgrene, flest i skydning, sejlsport og atletik.

Norge, Finland og Danmark har altså vundet markant færre medaljer end Sverige ved sommer-OL, men Sverige har ikke siden årtusindskiftet været bedste nordiske nation ved sommer-OL. Den position blev overtaget af Norge i Beijing 2008 og af Danmark i Athen 2004, London 2012 og Rio 2016.

Norge, Finland og Sverige var sammen med 13 andre lande repræsenteret ved de første olympiske vinterlege i Chamonix 1924. Og alle tre nationer har herefter været særdeles flittige medaljevindere ved vinter-OL - især Norge, der indtil dato har vundet i alt 329 medaljer (118 guld-, 111 sølv og 100 bronzemedaljer) ved vinter-OL i 10 forskellige sportsgrene, flest i langrend, hurtigløb på skøjter og skiskydning. Norge er hermed den nation i verden, som har vundet fleste medaljer ved samtlige vinter-OL - efterfulgt af stærke sportsnationer som USA, Tyskland, Østrig, Canada og Rusland. Finland har indtil dato vundet i alt 161 medaljer (42 guld-, 62 sølv- og 57 bronzemedaljer) ved vinter-OL i 10 forskellige sportsgrene, primært de nordiske skidiscipliner: Langrend, skiskydning og skihop. Sverige har indtil dato vundet i alt 143 medaljer (50 guld-, 39 sølv- og 54 bronzemedaljer) ved vinter-OL i 11 forskellige sportsgrene, flest i langrend, alpint skiløb og hurtigløb på skøjter. Danmark fik debut ved vinter-OL 1948 i St. Moritz og har på trods af deltagelse ved de fleste vinterlege hidtil kun vundet én medalje, nemlig sølvmedalje i curling for kvinder i Nagano 1998.

\section{FIRE FORSKELLIGE ELITESPORTSMODELLER I NORDEN}

De nordiske nationer oplevede - ligesom mange andre nationer i Vest- og Sydeuropa - i 1970'erne og 80'erne en markant nedgang i antallet af medaljer ved sommer-OL. Årsagen var ikke mindst, at Sovjetunionen og en række østeuropæiske nationer investerede massive økonomiske ressourcer i at opbygge og udvikle centralt styrede eliteidrætsmodeller, der også anvendte systematisk brug af doping ${ }^{15}$.

15 Heinilä, K. (1984): The totalization process in international sport I: Ilmarinen, M. (ed.): Sport and International Understanding (Berlin: Springer-Verlag); Hunt, T.M. (2007): Drug Games: The International Politics of Doping and the Olympic Movement, 1960-2007 (University of Texas at 
Derudover begyndte nationer i Sydøstasien - ikke mindst Kina, Korea og Japan - at bruge flere og flere økonomiske ressourcer kombineret med videnskabelige metoder til at opnå sportslig succes og national prestige igennem sportslige resultater ved internationale mesterskaber. Den globale udvikling med stigende nationale "investeringer" i eliteidræt var årsagen til, at politikere - både i og udenfor sportens verden - begyndte at drøfte og udvikle nationale eliteidrætsmodeller. Udgangspunktet for disse drøftelser i Danmark, Norge, Sverige og Finland var den nordiske velfærdsmodel, som tidligere omtalt.

I begyndelsen af 1980'erne tog skiftende regeringer i Danmark initiativ til at udarbejde "Lov om eliteidræt", der skulle udvikle dansk eliteidræt på en social og samfundsmæssig forsvarlig måde. Hensigten var at etablere en "offentlig, selvejende institution", der skulle forbedre danske atleter og holds sportslige resultater ved internationale mesterskaber, samtidigt med at atleternes sociale, uddannelsesmæssige og økonomiske forhold ikke blev nedprioriteret på grund af atleternes stigende trænings- og konkurrenceomfang. Lov om eliteidræt blev vedtaget af Folketinget i december 1985 og hermed blev eliteidrætsinstitutionen Team Danmark stadfæstet gennem lovgivning ${ }^{16}$.

I samme tidsperiode var der også i Norge en tilsvarende idrætspolitisk debat med fokus på eliteatleternes rammer og vilkår, både på og udenfor sportsarenaerne. Debatten blev intensiveret, da Norge blev tildelt værtskabet for de olympiske vinterlege i Lillehammer 1994. Resultatet blev etableringen af Olympiatoppen - en afdeling af Norges idrettsforbund (NIF) med selvstændig politisk og administrativ ledelse ${ }^{17}$.

I Sverige har der ikke mindst i det seneste tiår været flere idrætspolitiske drøftelser om fordele og ulemper ved etablering af en autonom og selvstændig institution for svensk eliteidræt - i lighed med Team Danmark i Danmark og Olympiatoppen i Norge. Det er imidlertid stadig tre centrale aktører, som varetager forskellige roller og forskelligt ansvar i forhold til drift og udvikling af svensk eliteidræt, nemlig Sveriges Olympiske Komité (SOK), Riksidrottsförbundet (RF) og de enkelte

Austin); Hunt, T.M., Dimeo, P., Hemme, F. \& Mueller, A. (2014): The Health Risks of Doping during the Cold War: A Comparative Analysis of the Two Sides of the Iron Curtain pp. 2230-2244 I: International Journal of the History of Sport, 31 (17) https://doi.org/10.1080/09523367.2014.922959 16 Hansen, J. (2012): The institutionalization of Team Denmark, pp. 43-61; Rasmus K. Storm (2012): Danish elite sport and Team Denmark: new trends, pp. 224-236 I: Andersen, S.S. \& Ronglan, L.T. (eds.): Nordic Elite Sport. Same ambitions - different tracks (Oslo: Universitetsforlaget) og Storm, R. K., Nielsen, K., \& Thomsen, F. (2016). Can a small nation be competitive in the global sporting arms race? The case of Denmark. Managing Sport and Leisure, 21(4), 181-202 doi:10.1080/23750 472.2016.1243993

17 Augestad, P. \& Bergsgard, N.A. (2007): Toppidrettens formel: Olympiatoppen som alkymist (Oslo: Novus Forlag); Goksøyr, M \& Hanstad, D.V: (2012): "Elite sport developmen in Norway - a radical transformation", pp. 27-42 og Andersen, S.S. (2012): "Olympiatoppen in the Norwegian sports cluster” pp. 237-256 I: Andersen, S.S. \& Ronglan, L.T. (eds.): Nordic Elite Sport. Same ambitions different tracks (Oslo: Universitetsforlaget). 
specialforbund, som f.eks. Svenska Fotbollförbundet (SvFF), Svenska Simförbundet (SSF) og Svenska Ishockeyförbundet (SIHA) ${ }^{18}$.

I Finland har den nationale olympiske komite igennem årtier været den centrale eliteidrætsorganisation, men overlappende strukturer i eliteidrætsorganisationer og politiske interesser på tværs af regioner har gjort det vanskeligt at udnytte de sportslige ressourcer og potentialer på en optimal måde. Finland har i forhold til de øvrige nationer i Norden bl.a. mange meget veludstyrede sports- og træningscentre fordelt over hele landet, men begrænset koordination af mål, strategier og ressourcer mellem de enkelte regionale centre. Derudover har der ofte været et dårligt samarbejde mellem klubber og forbund på lokalt og regionalt niveau i forhold til specialforbund og Suomen Olympiakomitea på nationalt niveau. Desuden blev finsk elitesport ramt af en stor doping-skandale i forbindelse med VM $2001 \mathrm{i}$ de nordiske skidiscipliner - en skandale, som betød at finsk elitesport tabte både penge, prestige og status, såvel blandt politikere, kommercielle partnere og ikke mindst befolkningen i Finland. De største udfordringer for finsk eliteidræt siden årtusindskiftet har været en uklar rolle- og ansvarsfordeling og manglende koordination og ledelse af finsk eliteidræt. På den baggrund etablerede Suomen Olympia-

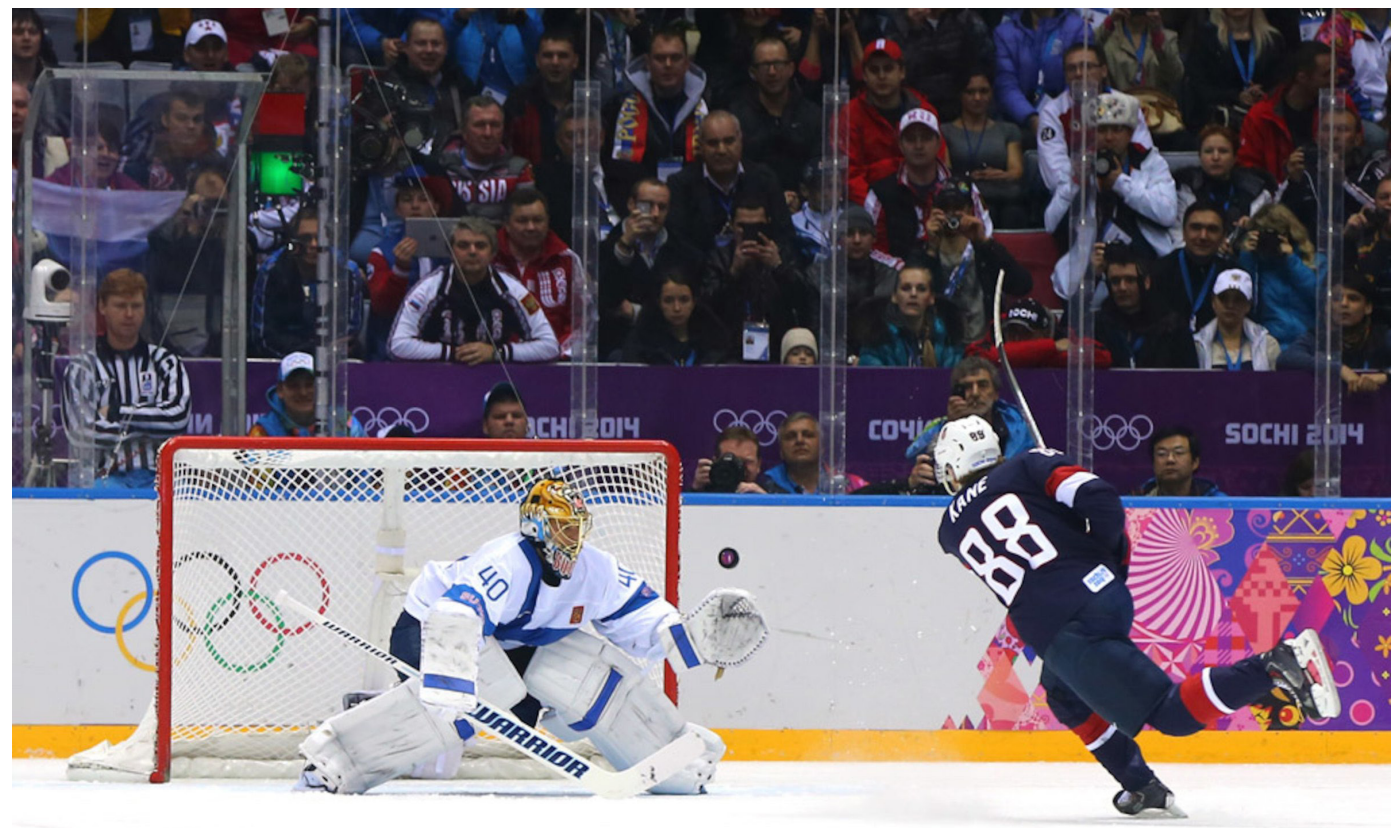

Finland vinder bronzemedalje i mændenes ishockeyturnering ved OL 2014 ved at besejre USA med 5-0 efter storspil af målmanden Tuukka Rask.

18 Norberg, J.R. \& Sjöblom, P. (2012): The Swedish elite sport system - or lack of it?, pp. 62-82 og Sjöblom, P. \& Fahlén, J. (2012): Swedish elite sport: contested terrain, pp. 191-208 I: Andersen, S.S. \& Ronglan, L.T. (eds.): Nordic Elite Sport. Same ambitions - different tracks (Oslo: Universitetsforlaget). 
komitea efter OL 2012 en afdeling for elitesport - High Performance Unit (HPU) - med ansvar for at koordinere og udvikle finsk elitesport på tværs af sportsgrene. Ideen og strukturen bag modellen blev hentet med inspiration fra bl.a. Norge (Olympiatoppen) og Danmark (Team Danmark). HPU under Suomen Olympiakomitea understøtter nu atleter, hold, trænere og forbund med direkte økonomisk tilskud og indirekte support i form af ekspertydelser inden for sportsmedicin, psykologi og ledelse, bl.a. i samarbejde med det nationale forskningscenter for eliteidræt (KIHU), som er placeret på Jyväskylä Universitet ${ }^{19}$.

\section{SPORTSLIGE RESULTATER 2013-2016: FLERE OPTURE END NED- TURE FOR DE NORDISKE NATIONER}

Der er altid stor opmærksomhed på og interesse for, hvordan de enkelte nationer klarer sig ved Olympiske Lege, som er verdens største sportsevent. Det har imidlertid også stor betydning, hvorledes de enkelte nationers atleter og hold præsterer ved Verdens- og Europamesterskaber og World Cups i de enkelte sportsgrene i årene forud for de olympiske lege. Flere og flere analyseinstitutioner anvender ikke kun OL-, VM- og EM-medaljer som målestok for en nations sportslige resultater, men i større og større omfang Top 8 placeringer ved OL og VM. Forklaringen er, at konkurrencetætheden i langt de fleste olympiske discipliner er blevet mere og mere intens, hvilket betyder at marginalerne mellem en medaljevinder og placering som nr. 4 eller 8 meget ofte er yderst beskeden ${ }^{20}$.

Norge er blandt verdens allerbedste vintersportsnationer, hvilket også kommer til udtryk gennem nationens placeringspoints i de seneste fire år. Ud af de samlede antal placeringspoints på 1.526 er 1.388 (91 \%) opnået i vintersportsgrene og kun 138 (9 \%) i sommersportsgrene. Norske atleter og hold har i de seneste fire år opnået en fremgang på 128 placeringspoints (9 \%) fra 1.398 (2009-2012) til i alt 1.526 placeringspoints (2013-2016). Fremgangen er imidlertid udelukkende sket i vintersportsgrene (1.388 placeringspoints i 2013-2016 vs. 1.152 placeringspoints i 2009-2012), mens der er en markant tilbagegang på 44 \% i sommersportsgrene (138 placeringspoints i 2013-2016 vs. 246 placeringspoints i 2009-2012). På baggrund af disse resultater forud for vinter-OL, var det heller ikke overraskende, at

19 Lämsä, J. (2012): Finnish elite sport - from class-based tensions to pluralist complexity, pp. 83-105 og Mäkinen, J. (2012): The anatomy of elite sports organization in Finland, pp. 209-223 I: Andersen, S.S. \& Ronglan, L.T. (eds.): Nordic Elite Sport. Same ambitions - different tracks (Oslo:Universitetsforlaget).

20 Den globale database - Gracenote (www.gracenote.com) indeholder de seneste 20 års resultater fra internationale mesterskaber i 50 olympiske sportsgrene. Mange analyser anvender et pointsystem, hvor en guldmedalje ved OL eller VM tæller 8 points, en sølvmedalje ved OL eller VM tæller 7 points, en bronzemedalje ved OL eller VM tæller 6 points etc. 
Sotji 2014 blev ét af Norges historisk bedste vinter-OL med i alt 29 medaljer (11 guld-, 7 sølv- og 11 bronzemedaljer). Rio 2016 blev derimod ét af Norges historisk dårligste sommer-OL med "kun" 4 bronzemedaljer og en placering som beskedne nr. 74 i nationskonkurrencen.

Tabel 1: Norge - Top 8 placeringer i olympiske discipliner 2013-2016

\begin{tabular}{|l|c|c|c|c|}
\hline & 2013 & 2014 & 2015 & 2016 \\
\hline Vintersport & 343 & 301 & 295 & 449 \\
\hline Sommersport & 42 & 36 & 30 & 30 \\
\hline I alt & 385 & 337 & 325 & 479 \\
\hline
\end{tabular}

Sverige er en nation, som traditionelt klarer sig rigtig godt, både i sommer- og vintersportsgrene. Det er også den tendens, som har kendetegnet resultaterne i 2013-2016. Svenske atleter og hold har i denne periode opnået 1.026 placeringspoints, hvilket er stort set det samme som i perioden 2009-2012, hvor der blev opnået 1.057 placeringspoints. Sverige vandt i 2013-2016 stort set lige mange placeringspoints i vintersportsgrene $(509=51 \%)$ som i sommersportsgrene $(517=51$ \%). Antallet af placeringspoints i vintersport er imidlertid faldet en del - fra 586 til 509 (13\%) og ikke mindst 2016 var resultatmæssigt et rigtig dårligt år for svensk vintersport. Sommersportsgrenene opnåede en beskeden fremgang på 10 \% (471 placeringspoints i 2009-2012 vs. 517 placeringspoints i 2013-2016) og denne fremgang blev også bekræftet ved Rio 2016, hvor Sverige vandt 11 medaljer - 3 medaljer flere end ved OL 2012 i London.

Tabel 2: Sverige - Top 8 placeringer i olympiske discipliner 2013-2016

\begin{tabular}{|l|c|c|c|c|}
\hline & $\mathbf{2 0 1 3}$ & $\mathbf{2 0 1 4}$ & $\mathbf{2 0 1 5}$ & $\mathbf{2 0 1 6}$ \\
\hline Vintersport & 137 & 149 & 136 & 87 \\
\hline Sommersport & 123 & 147 & 116 & 131 \\
\hline I alt & 260 & 296 & 252 & 218 \\
\hline
\end{tabular}

Finland er en nation, som traditionelt præsterer på et højt niveau i international vintersport. Finland opnåede i perioden 2013-2016 flest top 8 placeringer i vintersport $(278=66 \%)$ og en del færre $(141=34 \%)$ i sommersportsgrene. Finland har imidlertid oplevet en markant tilbagegang i vintersportsgrene, idet der kun 
blev opnået 278 placeringspoints i 2013-2016, hvilket er signifikant mindre end i 2009-2012, hvor finske atleter og hold opnåede 360 placeringspoints, altså et fald på 23 \%. Derimod har Finland haft en markant fremgang i sommersportsgrene, fra 110 placeringspoints i perioden 2009-2012 til 141 placeringspoints i perioden 2013-2016. Desværre kom denne fremgang ikke til udtryk ved OL 2016 i Rio, hvor finske atleter og hold "kun" vandt en bronzemedalje og opnåede meget få Top 8 placeringer - det dårligste resultat nogensinde for Finland ved sommer-OL og 2 medaljer færre end ved OL 2012 i London, hvor det blev til 2 sølv- og en bronzemedalje. De dårlige præstationer i Rio 2016 betød en yderst beskeden placering som nr. 78 i nationskonkurrencen.

Table 3: Finland - Top 8 placeringer i olympiske discipliner 2013-2016

\begin{tabular}{|l|c|c|c|c|}
\hline & 2013 & 2014 & 2015 & 2016 \\
\hline Vintersport & 84 & 71 & 57 & 66 \\
\hline Sommersport & 47 & 47 & 33 & 14 \\
\hline Total & 131 & 118 & 90 & 80 \\
\hline
\end{tabular}

Danmark har, især i det seneste tiår, klaret sig rigtig godt i sommersportsgrene. Danske atleter og hold har i perioden 2013-2016 opnået i alt 552 placeringspoints, hvilket er en flot fremgang fra perioden 2009-2012, hvor der blev opnået i alt 508 placeringspoints - en stigning på $9 \%$. Der var tale om en fremgang i såvel vintersportsgrene (12 placeringspoints i 2009-2012 vs. 23 placeringspoints i 2013-2016) som sommersportsgrene (490 placeringspoints i 2009-2012 vs. 529 placeringspoints i 2013-2016). Det er påfaldende, at Danmark har opnået 96 \% af placeringspoints i sommersportsgrene og kun 4 \% i vintersportsgrene. Fremgangen kom også markant til udtryk ved OL 2016 i Rio, hvor danske atleter og hold vandt 15 medaljer- det bedste danske OL-resultat siden 1948. Lidt overraskende opnåede danske atleter og hold - på trods af de 15 medaljer - færre placeringspoints ved Rio 2016 (135) end ved London 2012 (148).

Tabel 4: Danmark - Top 8 placeringer i olympiske discipliner 2013-2016

\begin{tabular}{|l|c|c|c|c|}
\hline & 2013 & 2014 & 2015 & 2016 \\
\hline Vintersport & 6 & 6 & 1 & 10 \\
\hline Sommersport & 133 & 129 & 132 & 135 \\
\hline I alt & 139 & 135 & 133 & 145 \\
\hline
\end{tabular}




\section{SOTJI 2014: DET HISTORISK BEDSTE VINTER-OL FOR NORGE OG SVERIGE}

Både Sverige og Norge opnåede historisk gode resultater ved Sotji 2014, hvor atleter og hold fra 88 nationer konkurrerede om OL-medaljer i 15 forskellige sportsgrene.

Norge vandt i alt 29 OL-medaljer i 6 forskellige sportsgrene: Langrend, skiskydning, nordisk kombineret, alpint skiløb, snow board og skihop. Resultatet betød, at Norge blev vinder af nationskonkurrencen ved OL 2014 - efterfulgt af stærke vintersportsnationer som USA med 30 OL-medaljer, men "kun" 9 af guld, Canada med 25 OL-medaljer og værtsnationen Rusland med 20 OL-medaljer. Rusland vandt egentligt 33 medaljer under legene, men er efterfølgende blevet frataget hele 13 OL-medaljer på grund af doping. De 29 norske OL-medaljer var seks OL-medaljer flere end Vancouver 2010 og ét af de højeste antal medaljer nogen sinde. De største norske OL-profiler i Sotji var Marit Bjørgen (langrend) med 3 guldmedaljer og Ole Einar Bjørndalen (skiskydning) med 2 guldmedaljer.

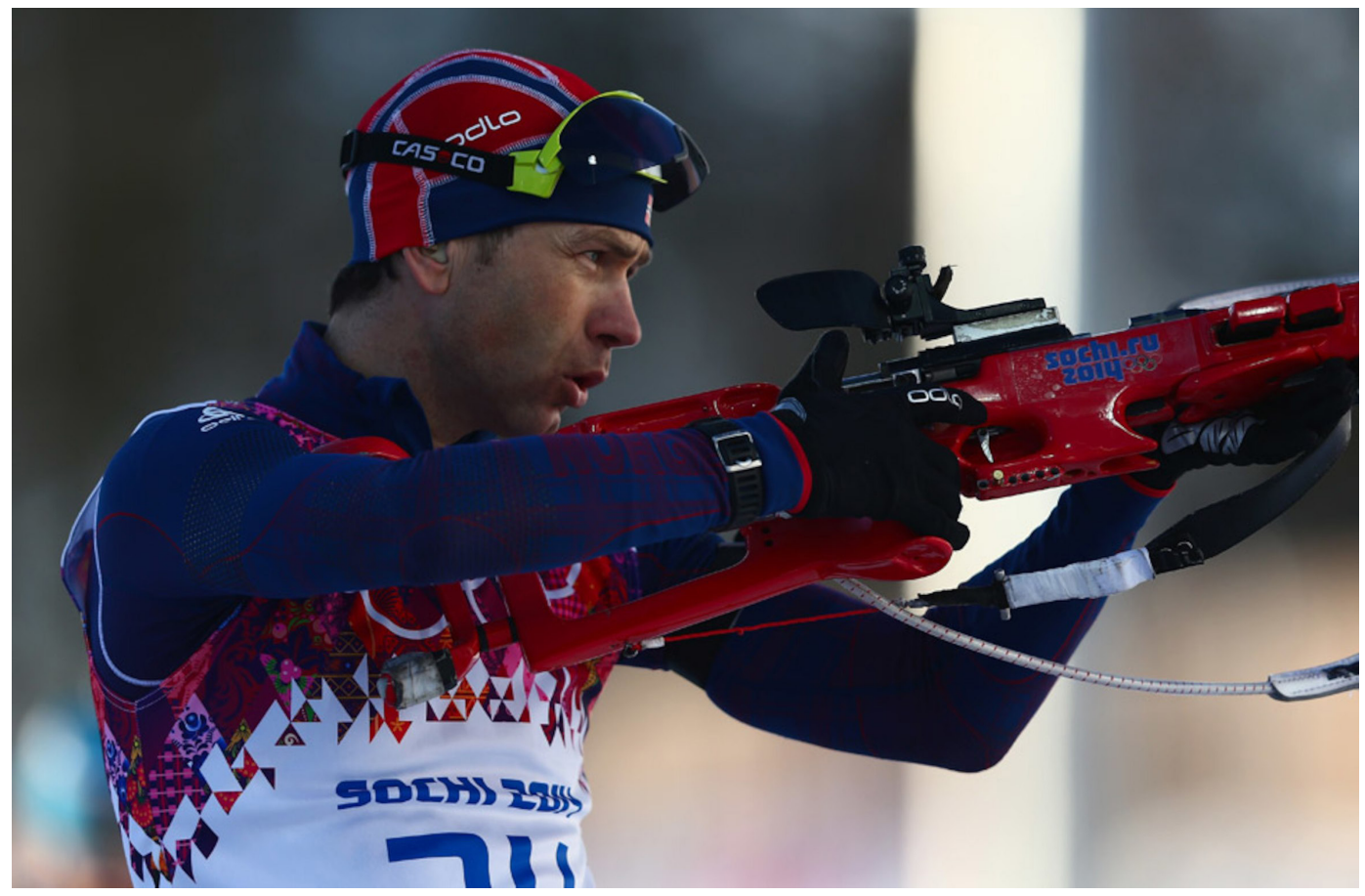

Norges Ole Ejnar Bjørndalen vinder OL-guld i $10 \mathrm{~km}$ sprint i 2014 og bliver hermed den mest vindende mandlige atlet ved vinter-OL med $\mathrm{i}$ alt 13 medaljer: 8 guld-, 4 sølv- og en bronzemedalje fordelt på 5 olympiske lege. 
Sverige vandt i alt 15 OL-medaljer (2 guld-, 7 sølv- og 6 bronzemedaljer), hvilket var fire medaljer flere end Vancouver 2010 og det højeste medaljeantal for svensk vintersport nogensinde. Medaljerne blev vundet i kun fire sportsgrene: Langrend (11), curling (2), ishockey (1) og free style skiing (1). De største svenske profiler ved OL 2014 var Charlotte Kalla (langrend) med 3 medaljer (en guld- og to sølvmedaljer) og "Tre Kronor", som vandt OL-sølv i mændenes ishockeyturnering efter finalenederlag mod Canada.

Finland vandt i alt 5 medaljer ( 1 guld, 3 sølv- og 1 bronzemedalje ved vinter-OL 2014 i Sotji - det samme antal som ved vinter-OL 2010 i Vancouver, hvor det blev til en sølv- og 4 bronzemedaljer. Medaljerne i 2014 blev vundet i tre sportsgrene: Langrend (3), snow board (1) og mændenes ishockeyturnering. De største finske OL-profil i Sotji var Iivo Niskanen og Sami Jauhojärvi, der overraskende blev olympiske mestre i mændenes holdsprint, Enni Rukajärvi med sølvmedalje i snow board og ishockeyholdet for mænd, der bl.a. vandt over værtsnationen og favoritterne til guldmedaljer - Rusland - i kvartfinalen, for derefter at tabe knebent 2-1 til ærkerivalerne fra Sverige i semifinalen.

Danmark var repræsenteret i tre sportsgrene ved vinter-OL 2014: Curling, langrend og alpint skiløb, men også denne gang uden medaljegevinst.

\section{RIO 2016: DET HISTORISK BEDSTE SOMMER-OL FOR DANMARK}

Danmark tog til gengæld revanche ved Rio 2016, hvor 207 nationer dystede i 28 forskellige sportsgrene. Danske atleter og hold vandt historisk 15 OL-medaljer (2 guld-, 6 sølv- og 7 bronzemedaljer), hvilket var seks medaljer bedre end London 2012. Medaljerne blev vundet i hele ni forskellige sportsgrene: Cykling (3), roning (2), sejlsport (2), badminton (2), svømning (2), brydning (1), atletik (1), kajak (1) og håndbold (1) - også en fornem olympisk rekord for Danmark, som blev nr. 26 i nationskonkurrencen og nr. 3 i nationskonkurrencen pr. indbygger - kun overgået af New Zealand og Jamaica. De største danske OL-profiler i Rio var Pernille Blume, der meget overraskende blev olympisk mester i 50 meter fri stil (svømning) og håndboldherrernes OL-guld - efter at holdet havde vundet EM-guld (2008 og 2012) og VM-sølv (2011 og 2013).

Sverige vandt 11 OL-medaljer (2 guld-, 6 sølv- 3 bronzemedaljer) i Rio 2016, hvilket også var en markant fremgang i forhold til London 2012, hvor det "kun" blev til 8 medaljer (1 guld-, 4 sølv- og 3 bronzemedaljer) - ét af de dårligste sommer-OL resultater for Sverige. De 11 svenske OL-medaljer blev vundet i syv sportsgrene: Svømning (3), cykling (2), brydning (2), ridning (1), fodbold (1), golf (1) og skyd- 
ning (1). De største svenske OL-profiler i Rio var Sarah Sjöström (svømning) med 3 medaljer og Jenny Rissveds overraskende guldmedalje i mountain bike cykling.

Norge havde opnået meget beskedne resultater i sommersportsgrene i de tre år forud for Rio 2016 og denne tendens blev desværre bekræftet i Brasilien, hvor det "kun" blev til 4 medaljer - alle af bronze. Medaljerne blev vundet i tre sportsgrene: Roning (2), brydning (1) og håndbold for kvinder, hvor Norge vandt OL-guld både i Beijing 2008 og i London 2012. Antallet af OL-medaljer i Rio var det laveste antal for Norge siden Los Angeles 1984 og måske endnu mere overraskende opnåede norske atleter og hold relativt få top 8-placeringer, nemlig 30 placeringspoints i $2016 \bmod 44$ placeringspoints i 2012.

Finland oplevede desværre en række dårlige præstationer ved OL 2016 i Rio. Både i relation til medaljer og top 8 placeringer var legene en stor negativ skuffelse, ikke mindst sammenholdt med resultaterne ved Verdens- og Europamesterskaberne de tre år forud for legene i Rio. Finland var repræsenteret i 15 forskellige sportsgrene, men opnåede kun top 8 placeringer i tre sportsgrene: Boksning, atletik og sejlsport. Disse tre sportsgrene opnåede 14 placeringspoints i Rio mod 35 placeringspoints i London 2012. Den største - og eneste - finske OL-profil i Rio var Mira Potkonen, som vandt OL-bronze i boksning for kvinder.

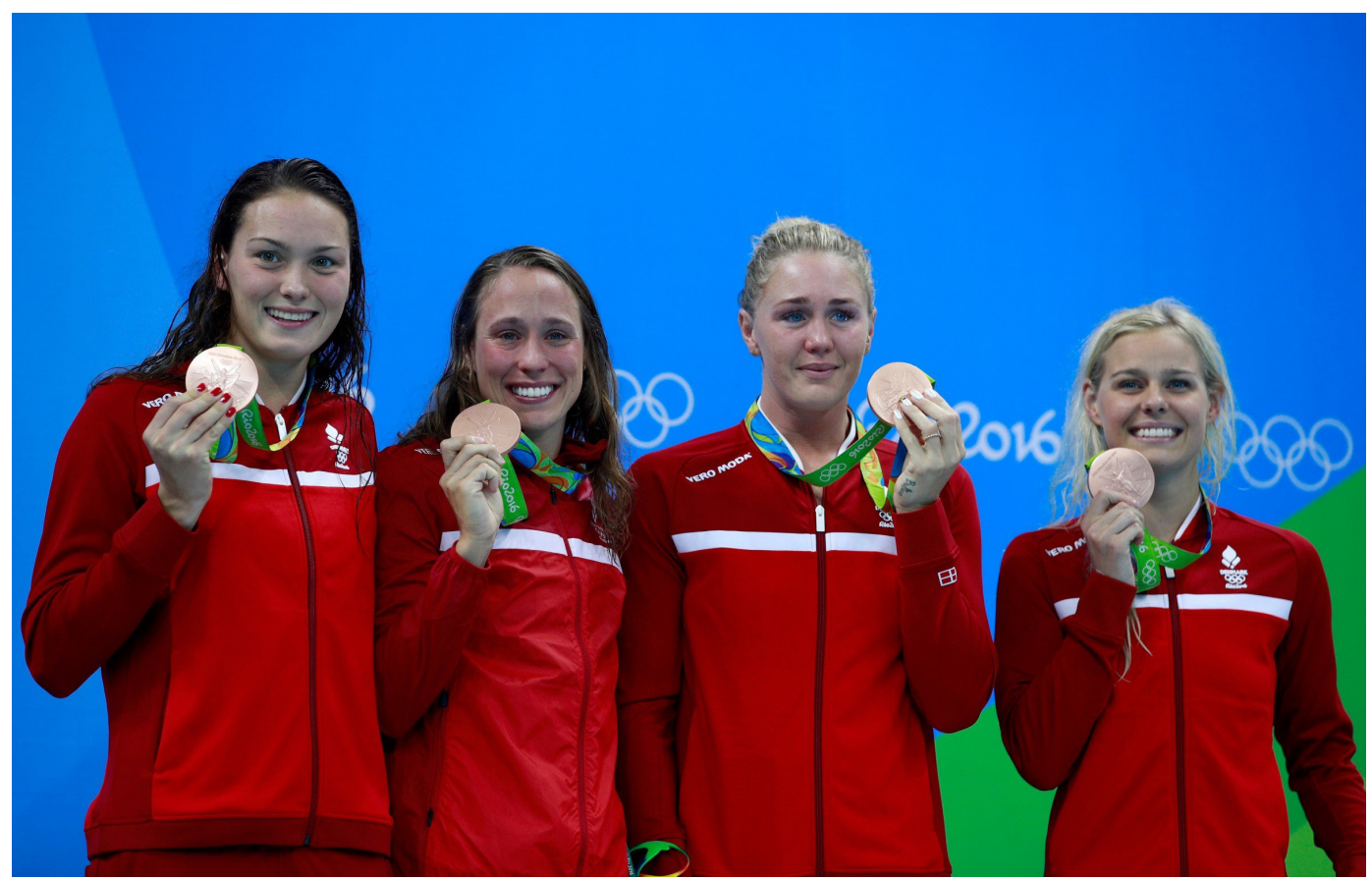

Danmark vandt overraskende OL-bronze i 4 × 100 meter medley ved OL 2016. Mie $\varnothing$. Nielsen, Rikke Møller Pedersen, Jeanette Ottesen og den olympiske guldvinder Pernille Blume slår den europæiske rekord med tiden 3:55.01, hvilket kun blev overgået af de stærke svømmenationer: USA og Australien. 


\section{INTERNATIONAL ELITEIDRAT ER MERE END OLYMPISKE SPORTS- GRENE}

Langt de fleste nationer fokuserer udelukkende på olympiske sportsgrene, men i de nordiske nationer er der også historiske traditioner for at støtte og udvikle ikke-olympiske sportsgrene. Dette er helt i overensstemmelse med den nordiske velfærdsmodel. Både Olympiatoppen, Team Danmark og High Performance Unit har samarbejde med specialforbund, som ikke har discipliner på det olympiske program.

Alle fire nordiske nationer er blandt verdens bedste i orienteringsløb. Sverige tilhører derudover verdenseliten i sportsgrene som bandy, floorball, speedway og bowling. Finland har dygtige sportsfolk i bl.a. motorsport, bowling og floorball. Danske atleter og hold er også blandt verdens bedste i sportsgrene som speedway, bowling og sportsdans, mens Norge har verdensklasse i sportsgrene som klatring, sportsdans, kick-boksning og rallycross. Derudover skal det nævnes, at årets sportsmand i Norge 2016 var verdensmesteren i skak - Magnus Carlsen.

De seneste år er der udarbejdet ranglister for alle nationer i både olympiske og ikke-olympiske sportsgrene ${ }^{21}$. Også i den sammenhæng placerer nationerne i Norden sig rigtig flot, ikke mindst i forhold til nationernes befolkningsstørrelse. Norge og Sverige har i hele perioden 2013-2016 været blandt de 20 bedste nationer i verden, mens Danmark opnåede sin hidtil bedste placering som nr. 20 i 2016. I forhold til befolkningsstørrelse har Norge - ikke mindst i kraft af sin dominans i vintersportsgrene - været verdens næstbedste sportsnation pr. indbygger i perioden 2013-2016, kun overgået af Slovenien (2013 og 2014), Jamaica (2015) samt tredjebedst efter New Zealand og Jamaica (2016). Sverige har også i hele perioden været blandt de 10 bedste sportsnationer pr. indbygger, mens Danmarks placeringer i 2013-2016 pr. indbygger har varieret mellem nr. 4 (2016) og nr. 14 (2014). Kun Finland ser ud til for alvor at miste terræn på de internationale ranglister. Finland var i 2016 for første gang i mange år ikke blandt verdens bedste 40 nationer, og Finland var heller ikke blandt verdens 10 bedste sportsnationer pr. indbygger i 2015-2016.

21 Den globale database - www.greatersportingnations.com - registrerer resultater i 98 forskellige sportsgrene (discipliner), både olympiske og ikke-olympiske. Blandt de ikke-olympiske kan bl.a. nævnes rugby, cricket, bandy, karate, skateboard og snooker. 
www.greatersportingnation.com

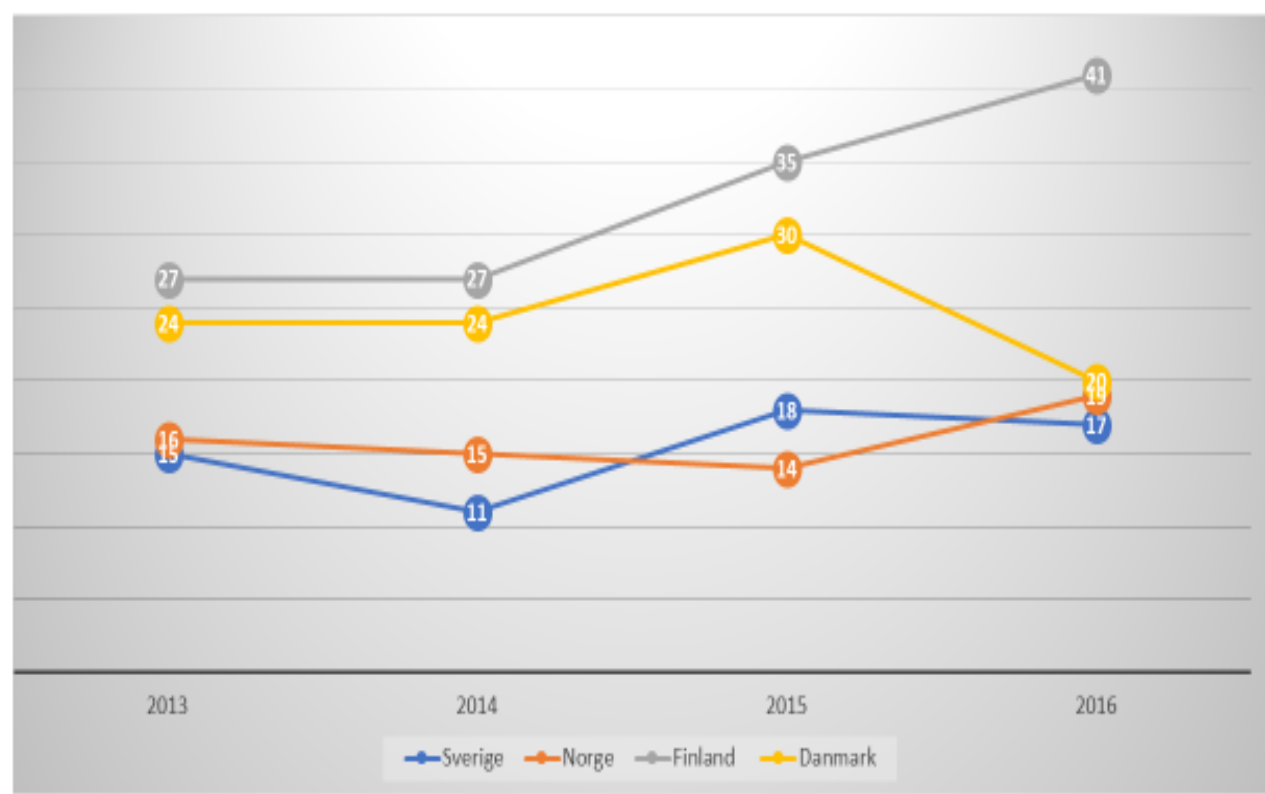

Rangliste over alle nationer $\mathrm{pr}$. indbygger Olympiske og ikke-olympiske sportsgrene 2013-2016 www.greatersportingnation.com

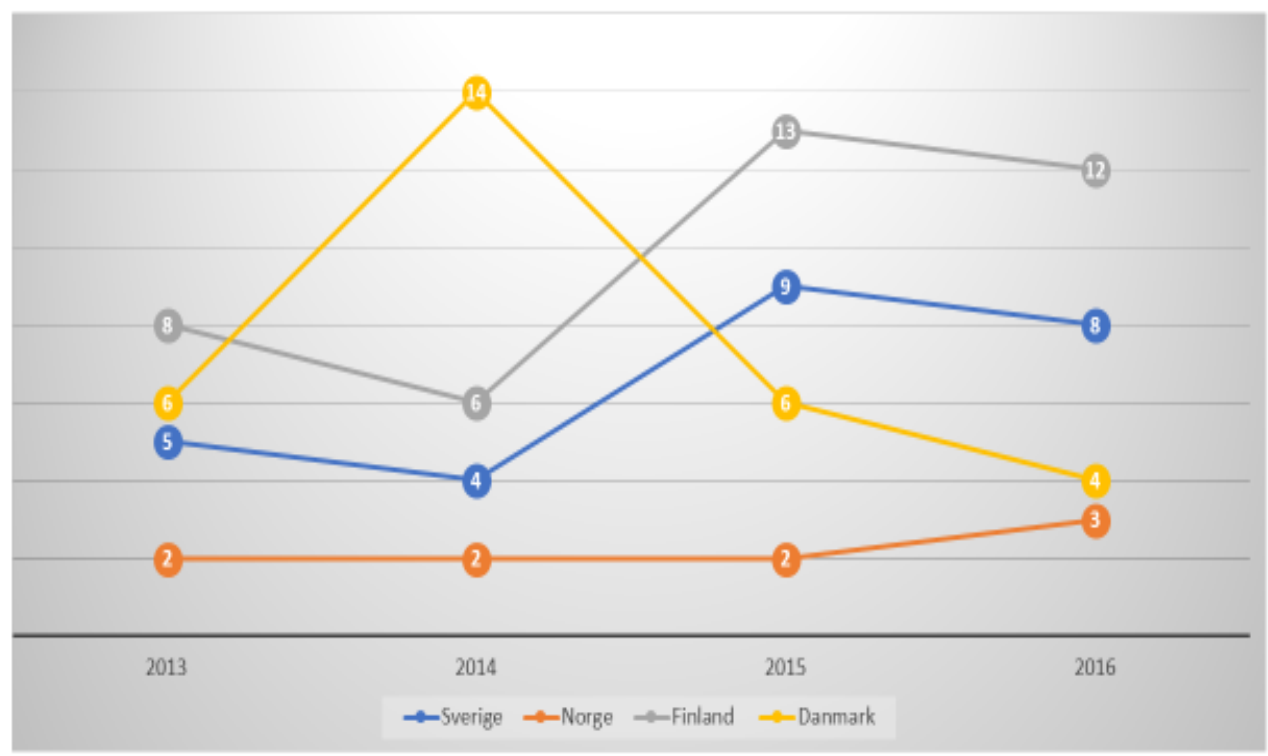




\section{KONKLUSION}

Som nævnt i indledningen er der en række metodiske udfordringer, som gør det vanskeligt entydigt at udpege den bedste sportsnation i Norden. Sverige er imidlertid den bedste sportsnation i Norden, såfremt der anlægges et historisk perspektiv for både olympiske og ikke-olympiske sportsgrene. Sverige er blandt verdens 20 bedste nationer i både sommer- og vintersportsgrene. Og målt i forhold til et relativt lavt indbyggertal på knap 10 mio. er Sverige blandt verdens 3 bedste sportsnationer. Det er dog værd at bemærke, at Sveriges resultater i de olympiske sommersportsgrene siden årtusindskiftet har været markant faldende, og der er helt sikkert et uudnyttet potentiale for Sverige i flere sommersportsgrene. Resultaterne ved Tokyo 2020 vil vise om svensk eliteidræt kan generobre pladsen som Nordens bedste sportsnation ved sommer-OL fra Danmark.

Norge er - både historisk og aktuelt - den suverænt bedste vintersportsnation i Norden. Både ved OL, VM og World Cups er der mange og stolte traditioner for norske atleter og hold på medaljeskamlerne. Det er absolut ikke urealistisk, at Norge bliver den bedste sportsnation ved vinter-OL 2018 - på trods af nationens beskedne indbyggertal på lidt over 5 mio. Norges konkurrenter til toppositionen som verdens bedste vintersportsnation er bl.a. Rusland med 142 mio. indbyggere, Tyskland med 82 mio. indbyggere, Canada med 36 mio. indbyggere og USA med 325 mio. indbyggere. Norge har også historisk opnået gode resultater ved sommer-OL, men London 2012 og især Rio 2016 var en markant skuffelse for Norge med "kun" 4 bronzemedaljer og et yderst beskedent antal top 8 placeringer. Der er absolut plads til forbedringer for Norge ved OL 2020 i Tokyo.

Finland er stadig blandt verdens 10 bedste vintersportsnationer med mange gode resultater ved vinter-OL, Verdensmesterskaber og World Cups. Og ikke mindst i ishockey, såvel for kvinder som mænd, er Finland blandt verdens absolut stærkeste nationer. Ud fra de seneste års resultater er det ikke urealistisk at Finland kan vinde 5 eller flere medaljer ved vinter-OL 2018. Til gengæld er der - i lighed med Norge - store forbedringspotentialer for Finland i forhold til resultaterne ved sommer-OL 2020 i Tokyo, både i forhold til medaljer og top 8 placeringer.

Danmark er aktuelt den bedste sommersportsnation i Norden. Der er mange årsager, bl.a. klima, geografi, manglende traditioner og svage træningskulturer i flere specialforbund, til at Danmark - i modsætning til Norge, Sverige og Finland - aldrig bliver en vintersportsnation. Derimod har danske atleter og hold i det seneste tiår forbedret resultaterne i sommersportsgrene markant. Både London 2012 med 9 medaljer og især Rio 2016 med 15 medaljer i 9 forskellige sportsgrene var historiske præstationer, som i de seneste år er blevet suppleret med verdensklasseresultater i bl.a. orienteringsløb, bowling, speedway og sportsdans. 


\section{LITTERATUR}

Allardt, E. (1975): Att ha, att älska, att vara: om väldfärd i Norden (Lund: Argos).

Augestad, P. \& Bergsgard, N.A. (2007): Toppidrettens formel: Olympiatoppen som alkymist (Oslo: Novus Forlag).

Andersen, S.S. (2012): "Olympiatoppen in the Norwegian sports cluster", pp. 237-256 I: Andersen, S.S. \& Ronglan, L.T. (eds.): Nordic Elite Sport. Same ambitions - different tracks (Oslo: Universitetsforlaget).

Bairner, A. (2010): What's Scandinavian about Scandinavian Sport, pp. 734-743 I: Sport in Society, 13/4 https://doi.org/10.1080/17430431003616555

Bergsgard, N.A. \& Norberg, R. (2010): Sport and Politics - the Scandinavian way, pp. 567582 I: Sport in Society, 13/4 https://doi.org/10.1080/17430431003616191

Bergsgard, N.A., Houlihan, B. Mangset, P. Nødland, S.I. \& Rommetveldt, H. (2007): Sport Policy: A comparative analysis of stability and change (Elsevier, UK).

Böhlke, N. \& Robinson, L. (2009): Benchmarking of elite sport systems, pp. 67-84 I: Management Decision, 47 (1) https://doi.org/10.1108/00251

Christensen, N.F., Petersen, K, Edling N., Haave, P. (red.) (2006): The Nordic Model of Welfare: An Historical Reappracusial (Museum Tuscalamum Pres, Copenhagen).

Dybdal, A. (red.) (2014): Socialdemokratiske tænkere (Informations Forlag, København).

De Bosscher, V., Bingham, J., Shibli, S., Van Bottenburg, M. \& De Knop, P. (2008): The global sporting arms race. An international comparative study on sport policy factors leading to international sporting success. (Meyer \& Meyer, Aachen).

De Bosscher, V., Shibli, S., von Bottenburg, M, De Knop, P. \& Truyens, J. (2010): Developing a method for comparing the elite sport systems and policies of nations: a mixed research methods approach. Journal of Sport Management, 24(5), pp. 567-60o https://doi. org/10.1123/jsm.24.5.567

De Bosscher, V., Shibli, S., Westerbeek, H. \& van Bottenburg, M. (2015): Successful Elite Sport Policies. An international comparison of the Sport Policy factors Leading to International Sporting Success (SPLISS 2.o) in 15 nations (Meyer \& Meyer Sport, Maidenhead).

Digel, H., Burk, V. \& Fahrner, M. (2006): High-performance sport - An international comparison. Edition Sports international 9 (Weilheim/Teck, Tubingen: Bräuer).

Esping-Andersen, G. (1990): The Three Worlds of Welfare Capitalism (Oxford: Polity Press).

Goksøyr, M. \& Hanstad, D.V. (2012): Elite sport development in Norway - a radical transformation, pp. 27-42 I: Andersen, S.S. \& Ronglan, L.T. (eds.): Nordic Elite Sport. Same ambitions - different tracks (Universitetsforlaget, Oslo). 
Green, M. \& Houlihan, B. (2005): Elite sport development. Policy learning and political priorities London \& New York: Routledge).

Hansen, J. (2012): The institutionalization of Team Danmark, pp. 43-61 I: Andersen, S.S. \& Ronglan, L.T. (eds.): Nordic Elite Sport. Same ambitions - different tracks (Universitetsforlaget, Oslo).

Heinilä, K. (1984): The totalization process in international sport I: Ilmarinen, M. (ed.): Sport and International Understanding (Berlin: Springer-Verlag).

Houlihan, B. \& Green, M. (2008): Comparative Elite Sport Development. Systems, structures and public policy (London, UK: Elsevier).

Hunt, T.M., Dimeo, P., Hemme, F. \& Mueller, A. (2014): The Health Risks of Doping during the Cold War: A Comparative Analysis of the Two Sides of the Iron Curtain pp. 2230-2244 I: International Journal of the History of Sport, 31 (17) https://doi.org/10.1080/095233 67.2014.922959

Hunt, T.M. (2007): Drug Games: The International Politics of Doping and the Olympic Movement, 1960-2007 (University of Texas at Austin, USA).

Larsen, C.A. \& Andersen, J.G. (red.) (2015): Den universielle velfærdsstat - funktionsmåde, folkelig opbakning og forandring (Frydenlund Academic).

Lämsä, J.: Finnish elite sport - from class-based tensions to pluralist complexity, pp. 83105 I: Andersen, S.S. \& Ronglan, L.T. (eds.): Nordic Elite Sport. Same ambitions - different tracks (Oslo: Universitetsforlaget).

Norberg, J.R. \& Sjöblom, P. (2012): The Swedish elite sport system - or lack of it?, pp. 6282 I: Andersen, S.S. \& Ronglan, L.T. (eds.): Nordic Elite Sport. Same ambitions - different tracks (Universitetsforlaget, Oslo).

Mäkinen, J.: The anatomy of elite sports organization in Finland, pp. 209-223 I: Andersen, S.S. \& Ronglan, L.T. (eds.): Nordic Elite Sport. Same ambitions - different tracks (Oslo: Universitetsforlaget).

Shibili, S., Bingham, J. \& Henry, I. (2007): Measuring the Sporting Success of Nations, pp. 61-81 I: Henry, I: Transnational and Comparative Research in Sport: Globalization, Governance and Sport Policy (London: Routledge).

Sjöblom, P. \& Fahlén, J. (2012): Swedish elite sport: contested terrain, pp. 191-208 I: Andersen, S.S. \& Ronglan, L.T. (eds.): Nordic Elite Sport. Same ambitions - different tracks (Universitetsforlaget, Oslo).

Storm, R.K. (2012): Danish elite sport and Team Denmark: new trends, pp. 224-236 I: Andersen, S.S. \& Ronglan, L.T. (eds.): Nordic Elite Sport. Same ambitions - different tracks (Universitetsforlaget, Oslo).

Storm, R. K., Nielsen, K., \& Thomsen, F. (2016). Can a small nation be competitive in the global sporting arms race? The case of Denmark. Managing Sport and Leisure, 21(4), 181202. doi:10.1080/23750472.2016.1243993 
Storm, R.K. \& Nielsen K. (2017): Er Skandinavien konkurrencedygtig? Danmark, Norge og Sveriges konkurrenceevne i international elitesport, pp. 363-380 I Busch, T., Olaussen, J. O. \& Pettersen, I. J.: Bred og spiss! NTNU Handelshøyskolen 50 år. En Vitenskabelig Jubilæumsantologi (Bergen: Fagbokforlaget).

Støckel. J.T., Strandbu, Å., Solenes, O. Jørgensen, P. \& Fransson, K. (2010): Sport for children and youth in the Scandinavian countries, pp. 625-643 I: Sport in Society, 13/4 https://doi.org/10.1080/17430431003616332

Wijk, J. (2012): The Swedish golf and tennis miracle - two parallel stories, pp. 109-130 I: Andersen, S.S. \& Ronglan, L.T. (eds.): Nordic Elite Sport. Same ambitions - different tracks (Oslo: Universitetsforlaget).

\section{Websites}

Badminton Danmark - www.badminton.dk

Danmarks Idrætsforbund (DIF) - www.dif.dk

International Olympic Committee - www.olympic.org/olympic-result

Gracenote - www.gracenote.com

Greatest Sporting Nation - www.greatersportingnations.com

Mental Floss - www.mentalfloss.com/article/55182/why-are-dutch-so-good-speed-skating

Norges idrettsforbund (NIF) - www.idrettsforbundet.no

Norges Skiskytterforbund - www.skiskyting.no

Olympian Database - www.olympiandatabase.com

Olympiatoppen - www.olympiatoppen.no

Riksidrottsförbundet (RF) - www.rf.se

SPLISS - www.spliss.net

Suomen Olympiakomitea - www.olympiakomitea.fi

Svenska Golfförbundet - www.swedishgolfallicance.com

Sveriges Olympiska Kommitté - www.sok.se

Team Danmark - www.teamdanmark.dk

\section{Fotos}

www.olympic.org 